\title{
Upaya Penurunan Tingkat Perilaku Agresif di Madrasah dengan Teknik Konseling Kelompok (Studi Kasus Pelanggaran Disiplin Aturan Madrasah) pada Siswa Kelas 7 F Semester Genap Tahun Pelajaran 2016/2017 MTSN Prambanan Kabupaten Klaten
}

\author{
Sri Hartini \\ MTsN I Prambanan
}

\begin{abstract}
The formulation of this research problem is that weather using group counseling technique can decrease aggressive behavior on VII student of MTs N Prambanan academic year 2016/2017 semester II or not? The research is done by using qualitative approach, that is class action research type. Stages of research conducted according to the stages proposed by Kemmis and Mc Taggart Subject researchers amounted to 30 students. The results showed that Behavior of aggressive attitude of $7 F$ grade students through group counseling service on cycle I 50\% for aggressive behavior of male students and 10\% for female students so as to decrease aggressive behavior of fight in school $96.6 \%$ to $36.6 \% 29$ students behave aggressively in two weeks reduced to 18 learners. With the decrease in the number of students as many as 11 students, then in cycle II of $96.6 \%$ decreased again to $10 \%$, which means there is a change of $86.6 \%$ is a significant decline. This shows that through the provision of group counseling services can decrease aggressive fighting behavior in schools at 7 7th grade students MTsN Prambanan Klaten District.
\end{abstract}

Keyword: aggressive behavior, group counseling

\begin{abstract}
Abstrak
Rumusan masalah penelitian ini adalah, Apakah dengan menggunakan teknik layanan konseling kelompok dapat menurunkan perilaku agresif pada siswa kelas VII MTs N Prambanan tahun pelajaran 2016/2017 semester II ? Penelitian dilakukan dengan menggunakan pendekatan kualitatif, yaitu jenis penelitian tindakan kelas. Tahapan penelitian dilakukan sesuai tahap yang dikemukakan oleh Kemmis dan Mc Taggart Subjek peneliti berjumlah 30 siswa. Hasil penelitian menunjukkan bahwa Perilaku sikap agresif siswa kelas $7 F$ melalui layanan konseling kelompok pada siklus I 50\% untuk perilaku agresif siswa laki-laki dan 10\% untuk siswa perempuan sehingga dapat menurunkan perilaku agresif bertengkar di sekolah sebesar $96.6 \%$ menjadi 36.6\% dengan jumlah penurunan dari 29 peserta didik berperilaku agresif dalam dua minggu berkurang menjadi 18 peserta didik. Dengan penurunan jumlah peserta didik sebanyak 11 peserta didik kemudian pada siklus II dari $96.6 \%$ mengalami penurunan lagi menjadi $10 \%$ yang berarti ada perubahan sebesar $86.6 \%$ ini merupakan penurunan yang cukup signifikan. Hal ini menunjukkan bahwa melalui pemberian layanan konseling kelompok dapat menurunkan perilaku agresif bertengkar di sekolah pada peserta didik kelas $7 F$ MTsN Prambanan Kabupaten Klaten.
\end{abstract}

Kata kunci: perilaku agresif, konseling kelompok 
Tabel 1. Hasil Pengamatan Keadaan Siswa Klas 7F dalam Perilaku Agresif Sebelum Tindakan

\begin{tabular}{|c|c|c|c|c|}
\hline No & Permasalahan Siswa/ Jenis Agresif Yang dilakukan & $\begin{array}{l}\text { Jumlah } \\
\text { Siswa }\end{array}$ & Nama Siswa & Keterangan \\
\hline 1 & Saling mengejek/Berkelahi saling & 2 siswa & Nico Damar dan Kuncoro & Klas 7f \\
\hline 2 & Saling Memukul/Berkelahi saling menjotos & 2 siswa & Tegar dan Nico Damar & Klas $7 \mathrm{f}$ \\
\hline 3 & Saling Mengolok-olok & 5 siswa & Serli dan Dewi Rumana & $\begin{array}{l}\text { Klas } 7 f \\
\text { Klas } 8 \mathrm{f}\end{array}$ \\
\hline 4 & $\begin{array}{l}\text { Saling Menyakiti dengan kaliamat yang kurang } \\
\text { enak didengar }\end{array}$ & 2 siswa & $\begin{array}{l}\text { Dwi Astuti dan Febrian } \\
\text { Candra }\end{array}$ & Klas $7 \mathrm{f}$ \\
\hline 5 & $\begin{array}{l}\text { Gojek berlebihan, pelecehan seksual yang } \\
\text { mengakibatkan orang tua wali murid menuntut } \\
\text { dan tidak terima }\end{array}$ & 4 siswa & $\begin{array}{l}\text { Kuncoro } \\
\text { Gading/Kurban } \\
\text { Fajar } \\
\text { Bagus Adi Tama }\end{array}$ & $\begin{array}{l}\text { Klas } 7 f \\
\text { Klas } 7 b \\
\text { Klas } 7 d \\
\text { Klas } 7 d\end{array}$ \\
\hline 6 & $\begin{array}{l}\text { Gojek berlebihan yang mengakibatkan jatuh, } \\
\text { siswa takut dan tidak mau sekolah lagi/dijegal } \\
\text { saat mau maju ke depan kelas }\end{array}$ & 2 siswa & $\begin{array}{l}\text { Febrian Oktavianto dan } \\
\text { Gilang }\end{array}$ & $\begin{array}{c}\text { Febrian } 7 \mathrm{f} / \\
\text { Kurban }\end{array}$ \\
\hline 7 & $\begin{array}{l}\text { Main sepak bola di dalam kelas saat pergantian } \\
\text { jam pelajaran yang mengakibatkan dua jendela } \\
\text { kaca pecah }\end{array}$ & 8 siswa & $\begin{array}{l}\text { Febri, Farhan, Toha, } \\
\text { Herlangga, Riski, Alan, } \\
\text { Jamal, Gilang, Ari, Diva }\end{array}$ & Klas $7 \mathrm{f}$ \\
\hline 8 & $\begin{array}{l}\text { Devi Fitriana payudara dipegang Niko dan } \\
\text { Febriyan Candra }\end{array}$ & 2 siswa & $\begin{array}{l}\text { Devi kurban } \\
\text { Niko dan febrian pelaku }\end{array}$ & Klas $7 \mathrm{f}$ \\
\hline 9 & $\begin{array}{l}\text { Dalah Faham karena merasa disepelekan bila } \\
\text { diajak bicara tidak menyenangkan akhirnya } \\
\text { kuncoro diajak gelut dan diantemi }\end{array}$ & 5 siswa & $\begin{array}{l}\text { Kuncoro/kurban } \\
\text { Priyanto } \\
\text { Ari Marantika } \\
\text { Mario } \\
\text { Gilang }\end{array}$ & $\begin{array}{l}\text { Klas7f } \\
\text { Klas 9e } \\
\text { Klas 9e } \\
\text { Klas 9e } \\
\text { Klas 8f }\end{array}$ \\
\hline 10 & $\begin{array}{l}\text { Bertengkar, cekcok/perang mulut } \\
\text { Serli sebagai sumber masalah bercerita ke Devi } \\
\text { menjelek-jelekan nama Dewi yang akhirnya } \\
\text { sampai jadi cekcok }\end{array}$ & 3 siswa & $\begin{array}{l}\text { Devi } \\
\text { Serli/sumber masalah } \\
\text { Dewi }\end{array}$ & $\begin{array}{l}\text { Klas } 7 \mathrm{f} \\
\text { Klas } 8 \mathrm{f} \\
\text { Klas } 7 \mathrm{f}\end{array}$ \\
\hline 11 & $\begin{array}{l}\text { Berkelahi farhan minta kertas Kuncoro tapi } \\
\text { Kuncoro tidak boleh dan bilang Bajingan, Farhan } \\
\text { tidak terima Kuncoro dikampleng } 3 \text { kali dan } \\
\text { jadilah berkelahi }\end{array}$ & 2 siswa & Farhan dan Kuncoro & Klas $7 f$ \\
\hline 12 & $\begin{array}{l}\text { Agung dan Devi saling mengejek dan mengolok- } \\
\text { olok karena agung melempar batu ke Devi, setiap } \\
\text { ketemu Agung, Devi selalu memanngil dengan } \\
\text { panggilan Munyuk Arab }\end{array}$ & 2 siswa & $\begin{array}{l}\text { Devi } \\
\text { Agung }\end{array}$ & $\begin{array}{l}\text { Klas } 7 f \\
\text { Klas } 7 \mathrm{e}\end{array}$ \\
\hline 13 & $\begin{array}{l}\text { Memecahkan jendela kaca klas } 7 \mathrm{~F} \text { bermain bola } \\
\text { saat pergantian jam pelajaran }\end{array}$ & 2 siswa & Tegar dan Niko & $7 \mathrm{f}$ \\
\hline
\end{tabular}

Sumber: Data Primer Diolah Tahun 2017

\section{PENDAHULUAN}

Peserta didik adalah individu yang sedang dalam masa perkembangan, dimana mereka senang dengan penjelajahan, mencari sesuatu yang baru sebagai bahan pertimbangan dalam mencari jati dirinya. Dalam masa pencarian jati diri tidak jarang mereka menemukan permasalahan atau persoalan dimana permasalahan tersebut dapat mereka selesaikan sendiri yang membuat dirinya semakin kaya pengalaman hidup namun kadang permasalahan itu tidak dapat mereka selesaikan sendiri yang membuat dirinya terbebani dan menghambat tugas tugas perkembangan dirinya. Individu yang mengalami hambatan dalam perkembangan dirinya biasanya mempengaruhi dalam hubungan sosialnya, mengingat manusia adalah makhluk individu dan sekaligus makhluk social.

Peserta didik kelas $7 \mathrm{~F}$ dalam hubungan sosialnya sering mengalami permasalahan yang di manifestasikan atau diwujudkan dalam 
perilaku agresif. Mereka sering bertengkar dengan teman, mulai dari mengejek, mengolok olok, mengancam, beradu fisik, memukul, menendang dsb. Perilaku tersebut merupakan bagian dari pelampiasan emosi peserta didik dimana mereka kurang memiliki daya pengendalian diri yang kuat sehingga untuk kepuasan hatinya mereka menyerang baik fisik maupun psikis orang lain ataupun dirinya sendiri. Mengingat permasalahan agresifitas merupakan peri laku yang melibatkan orang lain baik pribadi maupun kelompok maka diperlukan suatu bantuan yang dapat menangani permasalahan secara kelompok. yaitu pemberian layanan konseling kelompok.

Hasil pengamatan penulis pada siswa kelas VII F MTsN Prambanan Kabupaten Klaten tahun pelajaran 2016/2017 semester II baik pada saat pembelajaran di kelas maupun di luar kelas teramati bahwa sikap perilaku siswa agresif terhadap teman masih sering terjadi. Hampir setiap siswa sering usil, saling mengejek, mengolok-olok diantara teman, berkata kotor bahkan beratengkar dan berkelahi

Dari jumlah 30 siswa 29 siswa teridentifikasi telah melakukan agresifitas. Hasil pengamatan dari catatan kejadian dan dokumentasi yang ada di sekolah /madrasah dipaparkan dalam tabel 1.

Dari tabel 1 dapat dianalisa bahwa tingkat perilaku agresif pada observasi awal sebelum tindakan yang dilakukan siswa kelas VII F MTsN Prambanan Kabupaten Klaten mencapai $96,6 \%$ untuk mengurangi perilaku agresif yang terjadi pada siswa diperlukan strategi yang tepat. Salah satu alternatif adalah pelayanan konseling kelompok pada siswa. Keunggulan layanan konseling kelompok pada siswa adalah dengan adanya layanan bimbingan dan konseling yang diberikan memungkinkan peserta didik memperoleh kesempatan untuk pembahasan dan pengentasan permasalahan yang dialaminya melalui dinamika kelompok, sedang masalah yang dibahas adalah masalah pribadi yang dialami oleh masing masing anggota kelompok.

Dengan demikian pada perilaku agresif siswa dapat dipahami sebagai suatu tindakan yang bertujuan untuk melukai orang lain baik secara verbal maupun non verbal, secara fisik maupun non fisik baik langsung maupun tidak langsung. Mengingat perilaku agresif pada peserta didik merupakan gejala yang memprihatinkan pihak Guru dan Orang tua maka penulis berupaya mengadakan penelitian untuk menurunkan tingkat perilaku agresif pada pesera didik dengan memberikan layanan konseling kelompok.

\section{KAJIAN TEORI DAN PENGAJUAN HIPOTESIS \\ Pengertian Perilaku Agresif}

Perilaku agresif sering dikonotasikan sebagai sesuatu yang negatif dan suatu perusakan atau penyerangan, sehingga orang yang berperilaku agresif sering dianggap seseorang yang berbadan tinggi besar dan menakutkan karena dianggap mereka akan mengadakan penyerangan fisik. Penafsiran tersebut tidak semuanya salah namun tidak juga benar secara keseluruhan, ada sesuatu yang benar tapi ada juga kekeliruannya. Perilaku agresif dapat dipahami sebagai suatu perilaku yang bertujuan untuk meluka orang lain baik secara verbal maupun non verbal, secara fisik maupun psikis, langsung maupun tidak langsung (Anantasari, 2006; 80)

Dengan demikian dapat disimpulkan bahwa perilaku agresif adalahtindakan siswa yangdilakukan dengan sengaja ataupun tidak sengaja untuk menyakiti atau melukai orang lain. Perilaku agresif merupakan perilaku atau sikap bermusuhan, mengancam perilaku atau tindakan. Agresifitas adalah sikap yang bermusuhan yang ada pada diri manusia. Agresifitas ini dapat dilihat dari bentuk menyerang dan menghancurkan atau merusak, tetapi juga dalam bentuk sikap bermusuhan terhadap sesama manusia (Kurt Singer, 1991;148) Berdasarkan pengertian perilaku agresif di atas maka penulis menarik kesimpulan perilaku agresif adalah tindakan atau perilaku seseorang untuk melakukan penyerangan secara fisik dan psikis baik secara langsung maupun tidak langsung 


\section{Ciri-ciri Perilaku Agresif}

Berdasarkan pengamatan dan pandangan seseorang, perilaku agresif memiliki ciriciri sebagai berikut: cenderung untuk mengganggu, perilaku mengancam, menyerang dan menghancurkan atau merusak dan sikap bermusuhan kepada sesama manusia.

Dari beberapa ciri perilaku agresif tersebut tidak mesti keseluruhan ciri akan tampak untuk disebut perilaku agresif tetapi bisa satu atau lebih yang dimunculkan dalam perilaku agresif.

\section{Pengertian Konseling Kelompok}

Bimbingan dan konseling merupakan kegiatan yang terpadu dalam kegiatan pembelajaran di sekolah. Sekolah merupakan lembaga pendidikan formal yang melaksanakan kegiatan pembelajaran baik kurikuler, ko kurikuler maupun ekstra kurikuler dengan tujuan yang satu yaitu mencapai tingkat perkembangan yang optimal sesuai dengan tingkat perkembangannya. Salah satu kegiatan bimbingan dan konseling di sekolah adalah pemberian layanan konseling kelompok, mengenai pengertian dan seluk beluk tentang konseling kelompok akan penulis paparkan di bawah ini. Menurut Hallen (Halle) dalam bukunya disebutkan pengertian konseling kelompo sebagai berikut, Konseling kelompok adalah layanan bimbingan dan konseling yang memungkinkan peserta didik memperoleh kesempatan untuk pembahasan dan pengentasan permasalahan yang dialami melalui dinamika kelompok (Hallen. A. 82) Menurut Prayitno, 2001:89 disebutkan bahwa layanan konseling kelompok yaitu layanan bimbingan dan konseling yang memungkinkan peserta didik memperoleh kesempatan untuk pembahasan dan pengentasan permasalahan yang dialaminya melalui dinamika kelompok,masalah yang dibahas itu adalah masalah pribadi yang dialami oleh masing masing anggota kelompok. Menurut Latipun (2008:178) konseling kelompok merupakan salah satu bentuk konseling dengan memanfaatkan kelompok untuk membantu,memberi umpan balik (feed back) dan pengalaman belajar. Konseling kelompok dalam prosesnya menggunakan prinsip prinsip dinamika kelompok (group dynamic). Berdasarkan pengertian tersebut maka penulis mengambil garis besar bahwa konseling kelompok adalah suatu proses bantuan kepada sekelompok orang yang memeliki permasalahan hampir sama dengan menggunakan dinamika kelompok.

\section{Teknik yang Digunakan dalam Konseling Kelompok}

Mengingat dalam konseling kelompok dituntut adanya peran serta atau dukungan dari anggota kelompok agar tercapai tujuan atau memecahkan persoalan yang dihadapi bersama maka diperlukan adanya keterbukaan dan kesadaran dari tiap tiap individu untuk memberikan keterangan dan masukan secara jujur agar dapat diambil langkah langkah penyelesaian yang tepat dan bermakna. Adapun teknik yang digunakan dalam konseling kelompok adalah teknik umum dan permainan kelompok.

\section{Tahap Tahap dalam Konseling Kelompok}

Tahap pembentukan

Tahap peralihan

Tahap pelaksanaan kegiatan

Tahap pengakhiran

\section{Tujuan Konseling Kelompok}

Menurut Corey dalam Latipun (2008:181) disebutkan tujuan konseling kelompok sebagai berikut:

Belajar mempercayai diri dan orang lain; Mengembangkan pengetahuan dan perkembangan identitas yang baik; Mengetahui kebiasaan, kebutuhan dan masalah partisipan; Mengembangkan penerimaan diri, kepercayaan diri, harga diri untuk mencapai gambaran dirinya; Menemukan alternatif pemecahan masalah dan mengambil keputusan yang tepat dan konflik yang dialaminya; Untuk meningkatkan tujuan diri, otonomi dan rasa tanggung jawab pada diri dan orang lain; Mengetahui satu pilihan dan bisa membuat keputusan yang bijaksana; Membuat rencana khusus untuk mengganti perilaku tertentu dan berkomitmen untuk menjalankan rencana tersebut; Belajar secara lebih efektif tentang ketrampilan bergaul. 


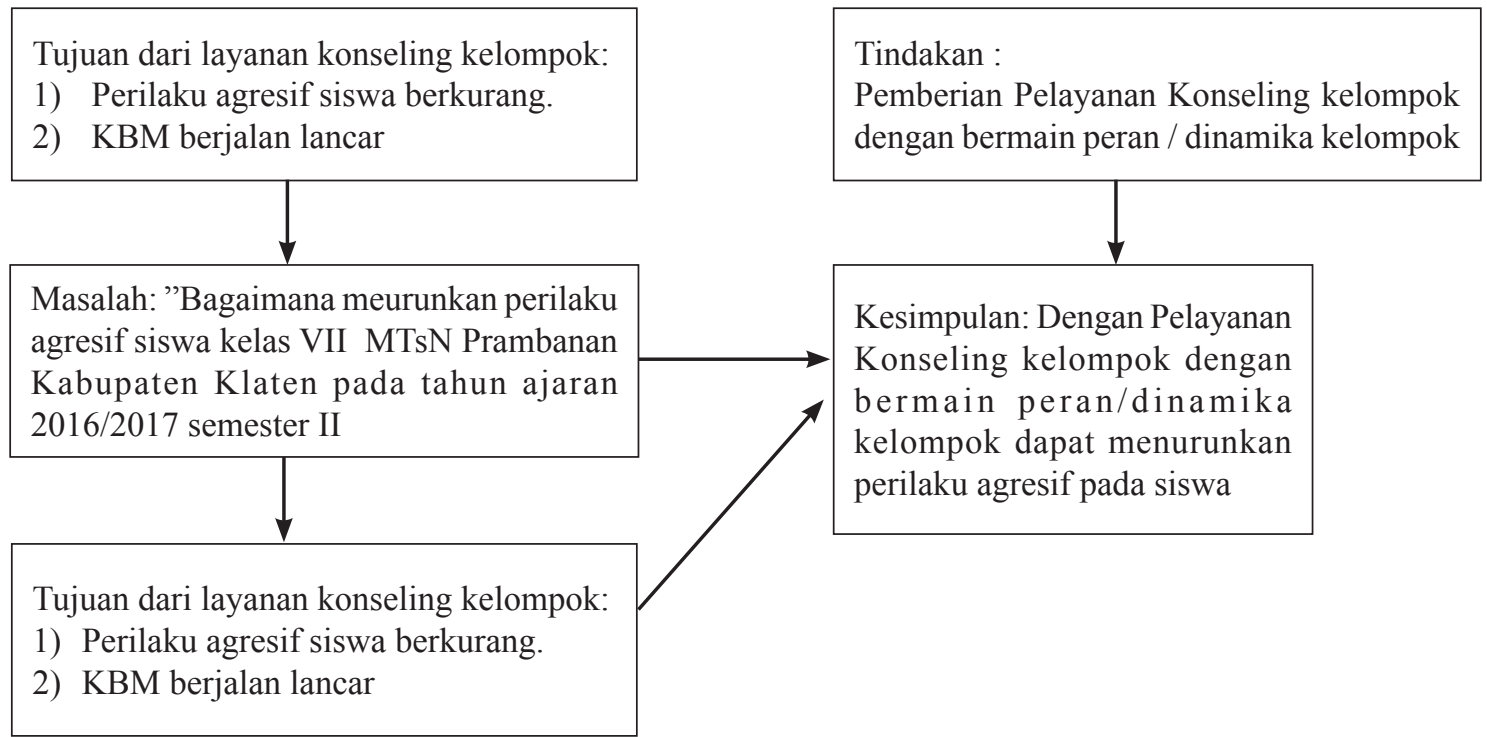

Gambar 1. Diagram Alur Kerangka Berfikir

\section{Dinamika Kelompok dalam Konseling Kelompok}

Dinamika kelompok merupakan motor penggerak dalam kegiatan konseling kelompok karena dengan dinamika kelompok inilah parapesertakonseling kelompok mendapatmanfaat untuk menyelesaikan permasalahan yang dihdapi.

Menurut Darwin Cartwright dalam Winkel (2004:599) ditunjukkan beberapa implikasi dari dinamika kelompok. Dinamika kelompok yaitu rasa keterikatan yang kuat terhadap kelompok, daya tarik kegiatan kelompok bagi masing masing anggota, relevansi dari sikap, pandangan dan perilaku yang akan diubah bagi semua anggota kelompok, penghargaan dari anggota yang satu terhadap yang lain,sehingga semua sumbangan pikiran dan perasaan diakui dan diterima. Kesempatan bersama mengenai tuntutan untuk merubah diri dan ke arah mana perubahan ini harus diusahakan.

Berdasarkan kajian teori yang disampaikan didepan bahwa perilaku agresif adalah sikap atau tindakan yang berusaha untuk menyakiti orang lain baik secara langsung maupun tidak langsung. Adapun penyebabnya adalah bisa berasal dari lingkungan keluarga, sekolah maupun masyarakat. Sedangkan Bimbingan dan Konseling adalah suatu bantuan psiko pendidikan dalam bingkai budaya, sehingga seseorang yang berperilaku agresif dapat kita kategorikan dalam perilaku menyimpang dari perilaku pada umumnya dan perlu mendapat bantuan. Mengingat dalam penelitian ini yang menjadi subyek penelitian ini adalah para peserta didik kelas 7F maka setting penelitiannya adalah dalam lingkungan sekolah tanpa mengabaikan adanya pengaruh dari lingkungan keluarga dan masyarakat. Peneliti sebagai salah satu guru BK di MTsN Prambanan Kabupaten Klaten memiliki kerangka pemikiran bahwa dengan layanan konseling kelompok yang diberikan oleh Guru BK di sekolah dapat menurunkan tingkat perilaku agresif pada peserta didik kelas 7F.

Berdasarkan uraian diatas penulis berpendapat bahwa terdapat hubungan yang erat perilaku agresif siswa dengan pelayanan konseling pada siswa sebagai sumber upaya penurunan perilaku agresif yang dilakukan siswa di MTs N Prambanan Kabupaten Klaten. Guna memperjelas kerangka berfikir pada penelitian ini berikut disajikan diagram alur kerangka berfikir seperti pada Gambar 1.

Berdasarkan permasalahan dan teori yang telah dikemukakan, maka hipotesis penelitian ini disusun sebagai berikut: "Periaku agresif pada siswa kelas VII MTsN Prambanan Kabupaten Klaten pada pembelajaran baik di dalam kelas maupun diluar kelas tahun pelajaran 2016/2017 semester II dapat berkurang melalui pelaksanaan layanan konseling kelompok. 


\section{METODE PENELITIAN}

\section{Setting dan Waktu Penelitian}

Dalam penelitian ini peneliti mengambil waktu pada semester genap tahun Pelajaran 2016/2017. Dengan alasan pada waktu semester gasal siswa MTsN Prambanan kususnya klas 7F sering terjadi pertengkaran dan bahkan perkelahian, untuk itu penulis melakukan penelitian ini dengan mengambil tindakan klas 7F sebagai subyek penelitiannya. Untuk jadwal penelitian peneliti membagi dalam 4 tahapan, tahap pertama adalah persiapan penelitian dimulai pada bulan Desember 2017 , tahap ke dua adalah pengumpulan data dan pembuatan proposal penelitian direncanakan pada bulan Januari 2017, tahap ke tiga adalah pembuatan instrument dan pelaksanaan tindakan direncanakan pada bulan Februari 2017, tahap ke empat adalah pembuatan laporan penelitian direncanakan pada bulan Maret 2017

\section{Tempat Penelitian}

MTs N Prambanan Jalan Manisrenggo

KM 2 Kabupaten Klaten

\section{Subjek Penelitian}

Peneliti mengambil subyek penelitian pada peserta didik kelas 7F yang berjumlah 30 anak dengan jumlah laki laki 18 dan perempuan 12. Berdasar laporan kegiatan Bimbingan dan
Konseling pada tahun pelajaran 2016/2017 semester gasal menun jukkan bahwa kelas $7 \mathrm{~F}$ paling banyak terjadi permasalahan baik dengan teman satu kelas maupun dengan teman lain kelas. Penyebab permasalahan kebanyakan karena kurangnya pengendalian diri, mudah emosi dan salah paham sehingga menimbulkan pertengkaran baik pertengkaran mulut sampai pertengkaran fisik. Untuk itulah dalam penelitian ini peneliti memilih mengambil kelas 7F sebagai subyek penelitian.

\section{Instrumen Penelitian}

Dalam keperluan penelitian perlengkapan yang peneliti gunakan adalah: Satuan layanan kegiatan konseling kelompok, Materi layanan konseling kelompok, Peralatan yang diperlukan dalam kegiatan konseling kelompok, Lembar kerja peserta layanan, Lembar evaluasi kegiatan layanan.

\section{Teknik Pengumpulan Data}

Dalam pengumpulan data yang diperlukan dalam penelitian tindakan kelas ini peneliti menggunakan teknik sebagai berikut :

\section{Observasi Partisipasif}

Yaitu pengamatan kepada suatu obyek dengan cara pengamat atau peneliti ikut berperan serta dalam kegiatan subyek penelitian

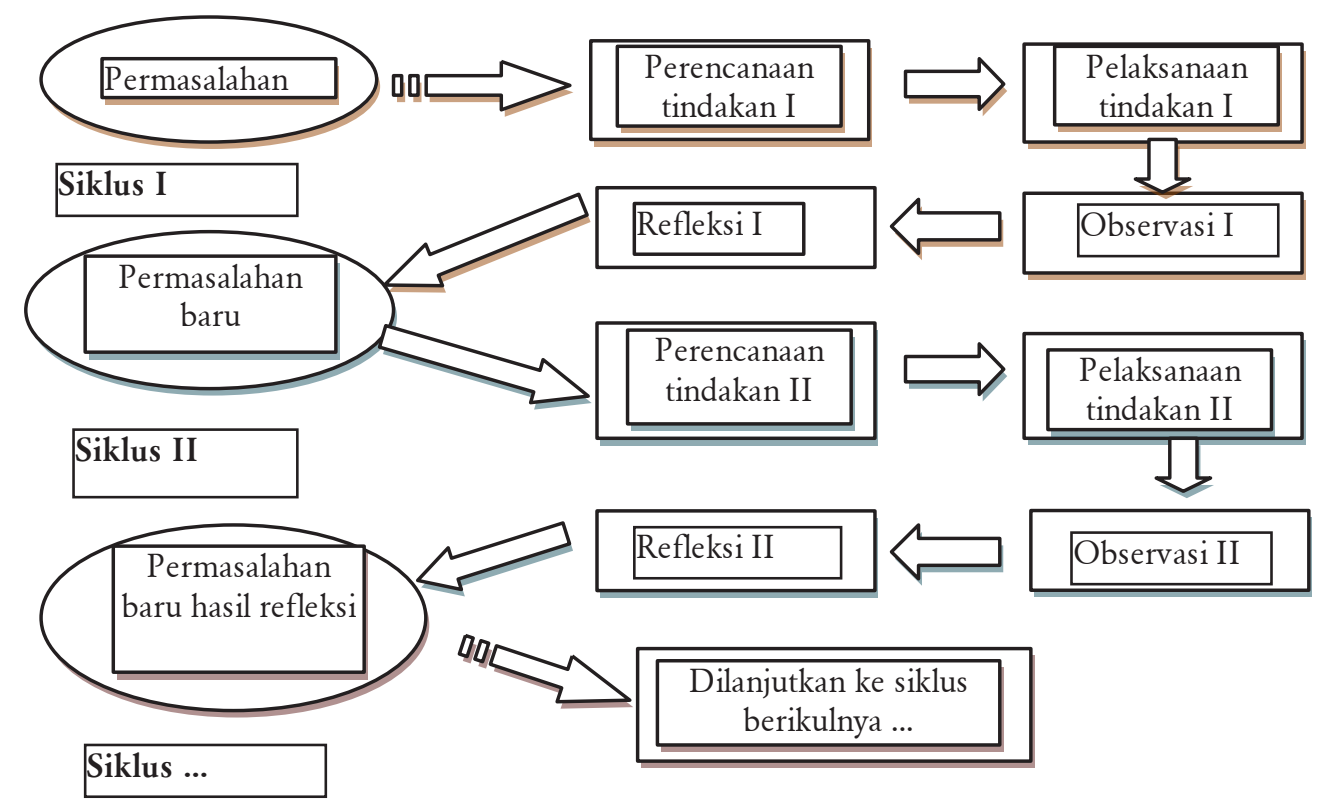

Gambar 2. Sepiral Kemmis S, MC Toggar R disertasi Suhardjono (2010) 
atau obyek yang sedang diamati Menurut Sudarwan Danim dalam Penelitian Tindakan Kelas (Iskandar: 2009:68) disebutkan bahwa Penelitian Tindakan Kelas berada di lapangan, peneliti atau kebanyakan berurusan dengan fenomena atau gejala social. Fenomena itu perlu didekati oleh peneliti dengan terlibat langsung pada situasi riel, tidak cukup meminta bantuan orang atau sebatas mendengar penuturan secara jarak jauh

\section{Wawancara}

Dalam penelitian ini peneliti akan mengadakan wawancara kepada sebagian subyek penelitian yang mewakili untuk memperoleh data tentang sikap atau perilaku agresif peserta didik kelas 7F digunakan sebagai cross ceks atas data yang diberikan oleh subyek penelitian.

\section{Studi dokumentasi}

Teknik ini merupakan penelaahan terhadap referensi-referensi yang yang berhubungan dengan focus permasalahan penelitian. Dokumendokumen yang dimaksud diantaranya adalah: Buku pribadi peserta didik, Rekapitulasi absensi peserta didik, Laporan kegiatan Bimbingan dan Konseling, Rekapitulasi permasalahan peserta didik, Laporan kegiatan konseling kelompok.

\section{Teknik Analisis Data}

Penelitian tindakan kelas ini dilaksanakan dalan dua putaran siklus dan setiap putaran siklus dilaksanakan dalam dua kali tatap muka. Rancangan dalam penelitian ini mengacu pada siklus kegiatan model spiral refleksi yang dikembangkan Kemmis dan Mc Taggart yaitu: perencanaan, pelaksanaan, pengamatan, dan refleksi.

\section{Siklus I}

\section{Perencanaan}

Menyusun rencana pelaksanan pelayanan konseling kelompok. Menyiapkan lembar kerja siswa. Menyiapkan sarana dan prasarana layanan. Menyiapkan lembar observasi. Menyiapkan angket sisiwa. Menyiapkan lembar evaluasi hasil layanan.

\section{Pelaksanaan}

Kegiatan awal

Guru mengecek kehadiran siswa. Guru menginformasikan tujuan pelaksanaan layanan konseling kelompok. Guru menjelaskan secara singkat permasalahan layanan dalam konseling kelompok. Guru mengadakan tanya jawab kepada siswa mengenai materi permasalahan yang sedang di bahas.

\section{Kegiatan inti}

Guru secara klasikal memberikan penjelasan tentang konseling kelompok dan dinamika kelompok yang akan dilaksanakan. Guru mengajak siswa bermain peran dan beberapa permainan yang dapat menumbuhkan rasa kebersamaan. Guru membagi siswa dalam kelompok-kelompok sesuai permasalahannya. Guru membimbing siswa dalam konseling kelompok dan siswa yang sedang melakukan dinamika kelompok. Siswa mengerjakan tugas dan berdiskusi dalam kelompok. Guru mengumpulkan hasil/menyimpulkan pekerjaan tiap-tiap kelompok.

\section{Kegiatan akhir}

Siswa mengerjakan evaluasi secara perorangan. Guru dan Siswa membahas hasil evaluasi secara perseorangan. Guru dan siswa membuat kesimpulan pelaksanaan layanan konseling kelompok yang telah dilaksanakan.

\section{Observasi}

Observasi dilakukan pada saat pelaksanaan layanan konseling kelompok berlangsung. Pada saat melakukan observasi peneliti dibantu oleh teman sejawat terutama dalam mengamati aktifitas yang dilakukan siswa dan aktifitas pelaksanaan layanan konseling yang disampaikan oleh guru.

\section{Refleksi}

Kegiatan refleksi dimaksud untuk mengetahui sejauh mana pelaksanaan tindakan dan menyusun langkah-langkah perbaikan yang akan dilaksanakan pada siklus selanjutnya. 
Tabel 2. Keadaan Agresif Siswa Sebelum Tindakan dan Siklus I

\begin{tabular}{lcccccccccc}
\hline Aspek yang diamati & \multicolumn{4}{c}{ Jumlah siswa } & \multicolumn{3}{c}{$\begin{array}{c}\text { Jumlah Perilaku agresif } \\
\text { Sebelum tindakan }\end{array}$} & \multicolumn{3}{c}{$\begin{array}{c}\text { Jumlah Perubahan Pelaku Agresif } \\
\text { Setelah tindakan Siklus I }\end{array}$} \\
\hline Siswa klas 7F & L & P & Jumlah & L & P & Jumlah & L & P & Perubahan \\
Sikap Siswa/agresif & 18 & 12 & 30 & 23 & 6 & 29 & 15 & 3 & $\begin{array}{l}\text { Laki-laki 8 } \\
\text { Perempuan 3 }\end{array}$ \\
\hline
\end{tabular}

Sumber: Data Primer Diolah Tahun 2017

\section{Siklus II}

Langkah-langkah pelaksanaan layanan konseling kelompok siklus II sama dengan langkah-langkah pelaksanaan layanan konseling pada siklus I. Perbedaan langkah tindakan antara siklus I dan siklus II adalah pada siklus I siswa hanya diperkenankan mengutarakan dan membahas salah satu permasalahan yang dialami sedangkan pada siklus II siswa diberikan kebebasan mengutarakan semua perlakuan agresif yang terjadi sesuai yang dialami siswa.

\section{HASIL PENELITIAN DAN PEMBAHASAN}

\section{Hasil Penelitian/Pelaksanaan Tindakan Tiap Siklus}

\section{Deskripsi Kondisi Awal}

Berdasarkan hasil evaluasi dan observasi diperoleh data pada kondisi awal penulis menjumpai masalah pada kebiasaan perilaku peserta didik kelas 7F Yang sering membikin ulah terutama perilaku emosional dan cenderung agresif sehingga hampir setiap hari ada kejadian tentang kelas 7F bertengkar di sekolah adalah seperti pada Tabel 2.

Berdasar hasil pengamatan penulis yang dilakukan selama dua minggu berturutturut mulai tanggal 9 Januari 2017 sampai 21 Januari 2017 diperoleh data 13 kali dapat dijelaskan bahwa pada siklus I terjadi laporan kasus pertengkaran pada peserta didik kelas 7F mencapai 96,6\%. Kasus tersebut terjadi pada waktu istirahat maupun pada waktu kegiatan pembelajaran berlangsung. Hal ini menunjukkan kurang adanya pengendalian diri serta kesalahan persepsi tentang laki laki itu harus berani bertengkar atau berkelahi.Kondisi ini dapat dilihat pada buku catatan kasus harian dari laporan kegiatan harian bimbingan dan konseling yang kebetulan adalah penulis sendiri, sehingga penulis dapat mengumpulkan data dari laporan kegiatan bimbingan dan konseling sekaligus sebagai laporan kegiatan harian. Dari pengamatan harian yang penulis lakukan menunjukkan adanya rasa acuh tak acuh dengan teman satu kelas, kurang adanya tepo seliro,kurang adanya rasa kebersamaan dengan teman satu kelas.

Hasil ini dilakukan sebelum tindakan dan masih belum mencapai indikator yang telah ditetapkan yaitu $100 \%$ agar siswa tidak melakukan tindakan agresif. Untuk memperjelas hasil layanan konseling kelompok terhadap perilaku agresif siswa klas $7 \mathrm{f}$ sebelum dan sesudah tindakan siklus I berikut disajikan diagram perkembangan perubahan perilaku agresif pada siswa kelas $7 \mathrm{f}$ sebelum dan sesudah tindakan seperti pada gambar 3 .

Dari hasil angket siswa dapat diketahui minat siswa dalam mengikuti layanan Konseling Kelompok dapat dipaparkan dalam tabel 3.

Dati tabel 3 tampak bahwa siswa lebih berminat dalam mengikuti layanan Konseling Kelompok dengan metode dinamika kelompok dari pada layanan konseling Individu. Hasil angket siswa siklus I disajikan dalam bentuk diagram gambar 4.

Hasil evaluasi terhadap adanya perubahan pada perilaku agresif siswa dapat ditunjukkan oleh tercapainya perubahan sikap perilaku agresif siswa yang disajikan pada tabel 4 .

Data tabel 4 tampak bahwa siswa ada perubahan dalam bersikap/agresif namunn siswa laki-laki masih harus diberikan layanan konseling kelompok masih ada beberapa siswa laki-laki yang melakukan agresif atau berkelahi dari siswa laki-laki yang melakukan agresif, bertengkar maupun berkelahi dari 15 anak $050 \%$ setelah diadakan layanan konseling kelompok jadi berkurang menjadi 7/23.3\% orang siswa sementara dari siswa prempuan 
Tabel 3 Hasil Angket Siswa Siklus I

\begin{tabular}{lll}
\hline Minat siswa & $\begin{array}{c}\text { Layanan Konseling Kelompok } \\
\text { dengan Metode Dinamika } \\
\text { Kelompok }\end{array}$ & \multicolumn{1}{c}{ Layanan Konseling Individu } \\
\hline Berminat & 14 (siswa yang Bermasalah ) & 16(Siswa yang tidak bermasalah ) \\
Tidak Berminat & 16 (Siswa yang tidak bermasalah ) & $14($ siswa yang Bermasalah ) \\
\hline Jumlah & 30 & 30 \\
\hline
\end{tabular}

Sumber: Data Primer Diolah Tahun 2017

Tabel 4. Hasil evaluasi terhadap adanya perubahan pada perilaku agresif siswa Siklus I

\begin{tabular}{lcccc}
\hline \multicolumn{1}{c}{ No } & $\begin{array}{c}\text { Laki-laki (Perilaku } \\
\text { Agresif Siklus I) }\end{array}$ & $\begin{array}{c}\text { Laki-laki (Perubahan } \\
\text { Perilaku Agresif Siklus } \\
\text { I) }\end{array}$ & $\begin{array}{c}\text { Perempuan (Perilaku } \\
\text { Agresif Siklus I) }\end{array}$ & $\begin{array}{c}\text { Perempuan (Perubahan } \\
\text { Perilaku Agresif Siklus } \\
\text { I) }\end{array}$ \\
\hline 1 & $15(50 \%)$ & $8(26.6 \%)$ & $6(20 \%)$ & $3(10 \%)$ \\
\hline $\begin{array}{l}\text { Jumlah } \\
\text { Perubahan }\end{array}$ & Laki-laki & $7(23.3)$ & Perempuan & $3(10 \%)$ \\
\hline
\end{tabular}

Sumber: Data Primer Diolah Tahun 2017

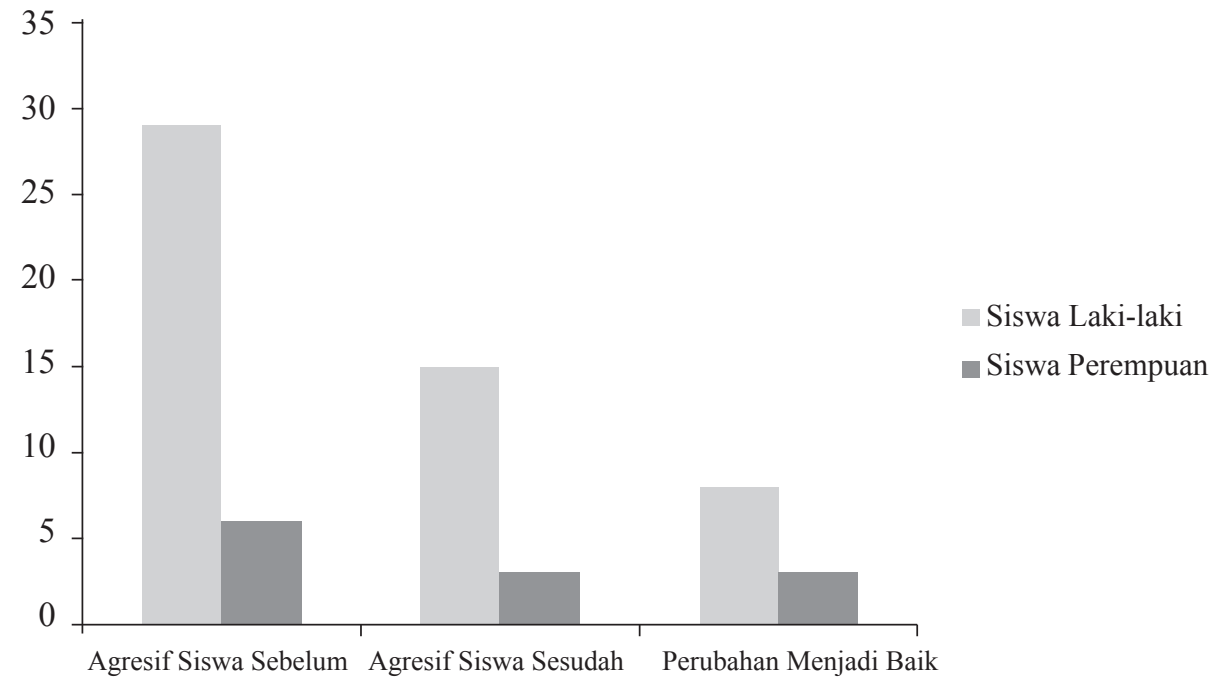

Gambar 3. Diagram Keadaan agresif Siswa sebelum dan sesudah pada pelaksanaan Siklus I

dari 6 anak $/ 20 \%$ menjadi 1 anak/3.3\% setelah diberikan layanan konseling kelompok sudah mengalami perubahan. Untuk memperjelas hasil sebelum dan sesudah tindakan siklus I terhadap sikap siswa selama pembelajaran baik saat didalam kelas maupun diluar kelas berikut disajikan diagram perkembangan perubahan sikap perilaku agresif pada siswa sebelum dan sesudah tindakan dapat dilihat pada gambar 5 .

\section{Deskripsi Siklus I}

Perencanaan Tindakan

Pada perencanaan tindakan kelas ini dilakukan dalam dua siklus yang berulang dan berkelanjutan dari siklus pertama dan siklus kedua. Setiap siklus terdiri dari empat tahap kegiatan yang meliputi : a. tahap oerencanaan. (planning), b. tahap implementasi tindakan (acting), c. tahap observasi (observing) dan d. tahap refleksi (reflecting). Penulis dalam penelitian ini menggunakan wahana sebagai materi penelitian adalah pemberian layanan konseling kelompok, karena penulis seorang guru bimbingan dan konseling yang berkecimpung di dalam masalah perkembangan dan perilaku peserta didik. 


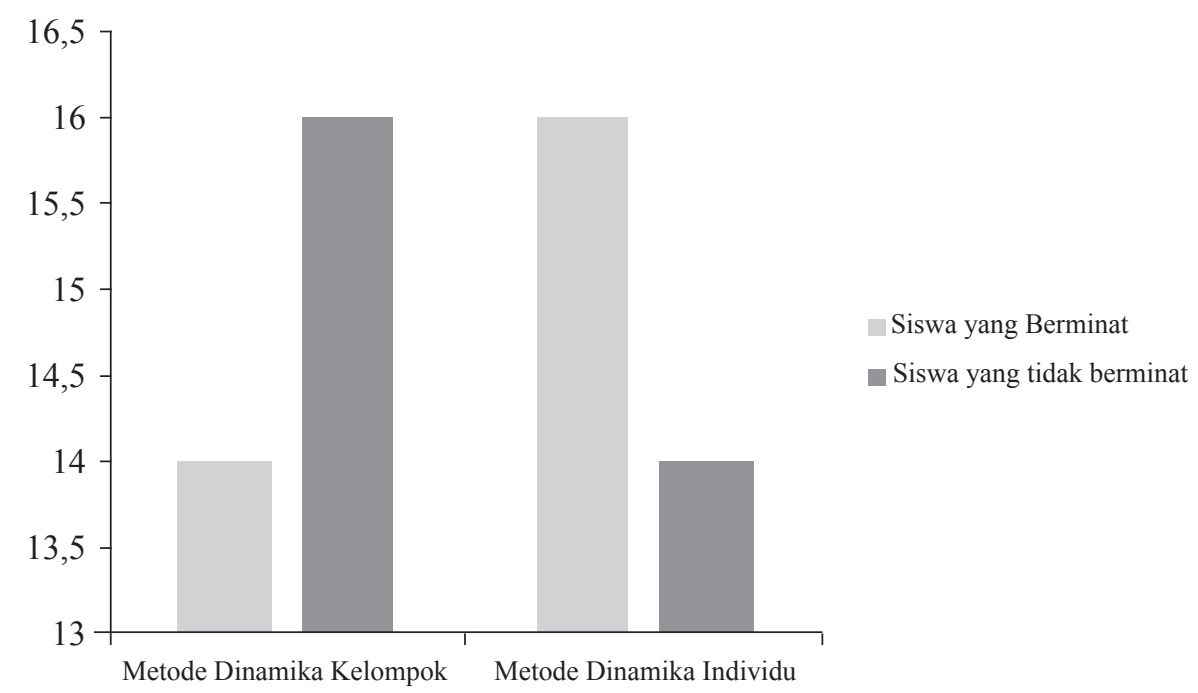

Gambar 4. Diagram Minat siswa dalam Layanan Konseling Kelompok dan Individu

\section{Pelaksanaan}

Pada kegiatan konseling kelompok ini memang sangat diperlukan adanya partisipasi dari semua anggota kelompok karena yang diutamakan adalah adanya dinamika kelompok untuk membantu menyelesaikan permasalahan yang dihadapi oleh peserta kelompok. Diharapkan semua peserta aktif berpendapat dan mencurahkan uneg-uneg dan permasalahan yang dihadapi masing masing yang tidak sengaja mungkin peserta lain akan dapat membaca permasalahan yang sebenarnya terjadi pada anggota kelompoknya sehingga mereka dapat memberikan masukan dan saran secara langsung maupun tidak langsung.

Berdasarkan pendapat dari para peserta diujung kegiatan inti penulis menjelaskan tentang pengertian yang benar tentanag perilaku agresif yang salah satunya adalah bertengkar di sekolah dan apa penyebab perilaku tersebut sering muncul pada seorang peserta didik. Dengan penjelasan dari pemimpin diskusi kelompok nampaknya mereka mulai memahami bahwa tidak harus setiap anak laki-laki itu pernah bertengkar/atau berkelahi di sekolah. Meskipun penulis telah memberikan gambaran dengan jelas, namun masih ada seorang anak laki-laki yang bertanya : apakah kita tidak boleh bertengkar kalau di sekolah saja, sedang di luar sekolah diperbolehkan? ( Kuncoro)

\section{Hasil Penelitian Siklus I}

Berdasarkan hasil evaluasi dan observasi yang dilakukan adanya peningkatan semangat dalam mengikuti kegiatan layanan konseling kelompok serta adanya perubahan perilaku

\section{Hasil Penelitian Siklus II Deskripsi Pelaksanaan Siklus 2}

Perencanaan Tindakan

Penulis merencanakan kegiatan siklus 2 dengan dua kali tatap muka atau dua pertemuan denganwaktu@2 X40 menit. Pada siklus 2 ini ada perubahan jumlah peserta tiap kelompok yang disampaikan. Untuk materi yang disampaikan pada siklus 2 adalah masih sama ,hanya berbeda pada jumlah peserta tiap kelompok pada siklus 1 berjumlah 9 dan 6 peserta sedang pada pelaksanaan tindakan siklus 2 berjumlah 5 peserta didik dalam tiap kelompok Siklus 2 pertemuan 1 akan dilaksanakan pada hari Rabu tanggal 8 Februari 2017. Penulis menggunakan jam pembiasaan budi pekerti dan jam layanan klasikal bimbingan dan konseling digabung menjadi berurutan yang kebetulan pengampunya adalah penulis sendiri.

\section{Pelaksanaan \\ Pada tenelitian tindakan kelas kali ini penulis mencatat adanya peningkatan perilaku positif pada peserta didik kelas 7F. Data yang}




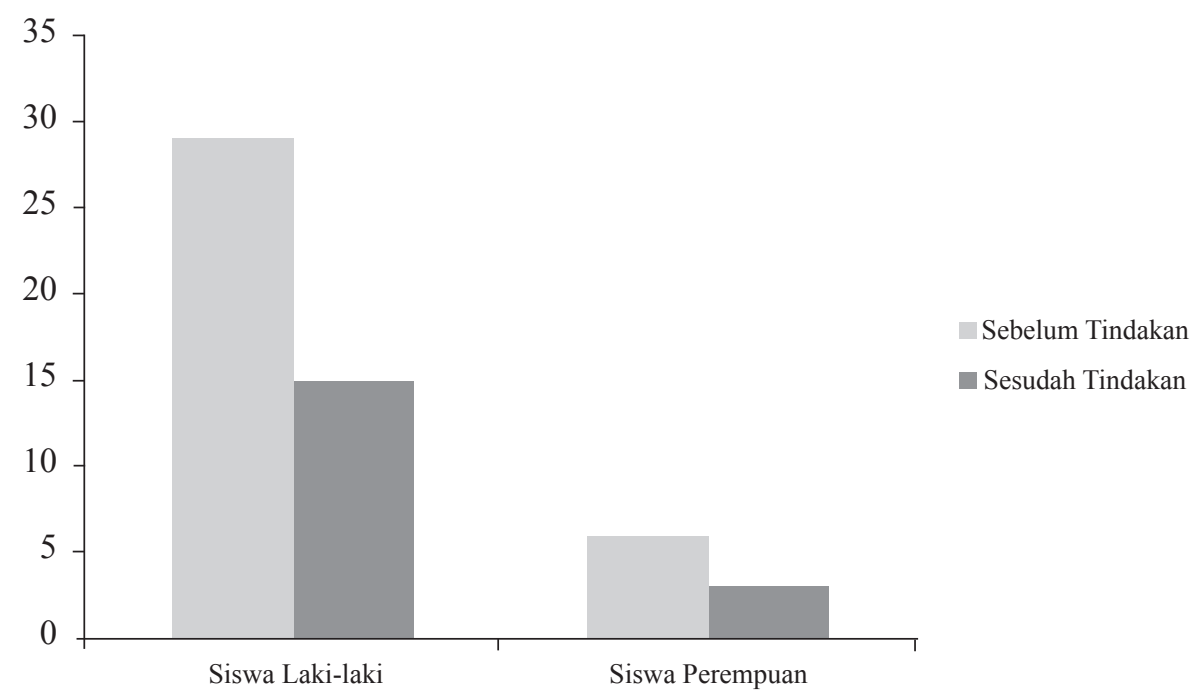

Gambar 5. Diagram perkembangan perubahan sikap perilaku agresif pada siswa sebelum Tindakan dan Siklus I

terkumpul dari hasil pengamatan kondisi awal menunjukkan jumlah peserta didik yang berperilaku agresif atau bertengkar di sekolah adalah 13 orang dalam kurun waktu 2 minggu atau 12 hari. Hal ini menunjukkan adanya kerawanan kelas tersebut dalam hal berperilaku agresif atau bertengkar di sekolah sebab mereka mudah sekali tersulut untuk suatu agresifitas atau suatu pertengkaran. Berdasarkan hasil jawaban yang penulis berikan baik secara tertulis maupun secara lesan menyatakan bahwa mereka merasa bangga jika bisa mengalahkan orang lain atau memenangkan suatu pertengkaran, sehingga mereka dengan mudahnya menyelesaikan masalah dengan cara bertengkar baik adu mulut ataupun adu fisik. Dengan jumlah peserta didik dalam satu kelas 30 anak sedang jumlah peserta didik yang bertengkar di sekolah dalam dua minggu ada 13 anak menunjukkan kerawanan yang tinggi yaitu $96,6 \%$.

Berdasarkan hasil evaluasi dan observasi diperoleh data tentang perubahan sikap perilaku agresif siswa setelah mengikuti konseling kelompok dengan bermain peran dalam kegiatan dinamika kelompok, siswa dalam mengungkapkan pikiran dan perasaan dapat dipaparkan dalam tabel 5.

Seperti tampak pada tabel 5 pada pelaksanaan layanan konseling kelompok siklus II semua siswa telah aktif mengikuti layanan.
Hasil observasi aktifitas dalam mengikuti kegiatan layanan siswa disajikan dalam bentuk diagram Gambar 6.

\section{Hasil Angket Siswa Siklus II}

Dari hasil angket siswa dapat diketahui minat siswa dalam mengikuti kegiatan layanan konseling kelompok dengan bermain/dinamika kelompok sebagaimana dipaparkan dalam tabel 6 .

Dati tabel 6 tampak bahwa siswa lebih berminat mengikuti kegiatann layanan konseling dengan bermain/dinamika kelompok daripada dengan konseling individu Hasil Anget siswa siklus II disajikan dalam bentuk diagram pada Gambar 7.

Hasil evaluasi terhadap adanya perubahan pada perilaku agresif siswa dapat ditunjukkan oleh tercapainya perubahan sikap perilaku agresif siswa yang disajikan pada tabel 7 .

Dari tabel 7 dapat dijelaskan bahwa pada siklus II tingkat pencapain terhadap adanya perubahan pada perilaku agresif siswa ada 26 siwa $/ 86,6 \%$. hasil ini lebih baik bila dibanding dengan hasil sikap agresif pada siklus I yaitu 15 siswa $/ 50 \%$. Sedangkan perubahan perilaku agresif siswa kelas $7 \mathrm{f}$ mengalami penuruna pada siklus I menjadi 15 siswa menjadi 26 pada siklus II. Hasil perubahan pada siklus I dan siklus II disajikan dalam bentuk diagram seperti pada Gambar 8. 
Tabel 5 Perubahan Sikap Perilaku Agresif pada Siswa Siklus II

\begin{tabular}{lccccccc}
\hline \multicolumn{7}{c}{ Jumlah siswa yang bersikap agresif } \\
\hline Aspek yang diamati & Awal & $\begin{array}{c}\text { Masih } \\
\text { melakukan } \\
\text { agresif }\end{array}$ & $\begin{array}{c}\text { Jumlah } \\
\text { perubahan }\end{array}$ & $\begin{array}{c}\text { Aspek yang } \\
\text { diamati }\end{array}$ & $\begin{array}{c}\text { Sikap } \\
\text { Agresif } \\
\text { Awal }\end{array}$ & $\begin{array}{c}\text { Masih } \\
\text { melakukan } \\
\text { agresif }\end{array}$ & $\begin{array}{c}\text { Jumlah } \\
\text { perubahan }\end{array}$ \\
\hline Siswa Klas 7f & L & L & & Siswa Klas 7f & P & P & \\
Sikap siswa/Agresif & 29 & 3 & 26 & Sikap siswa/ & 6 & 1 & 5 \\
& $(96.6)$ & $(10 \%)$ & $(86.6 \%)$ & Agresif & $(20 \%)$ & $(3.3)$ & $(16.6 \%)$ \\
\hline
\end{tabular}

Sumber: Data Primer Diolah Tahun 2017

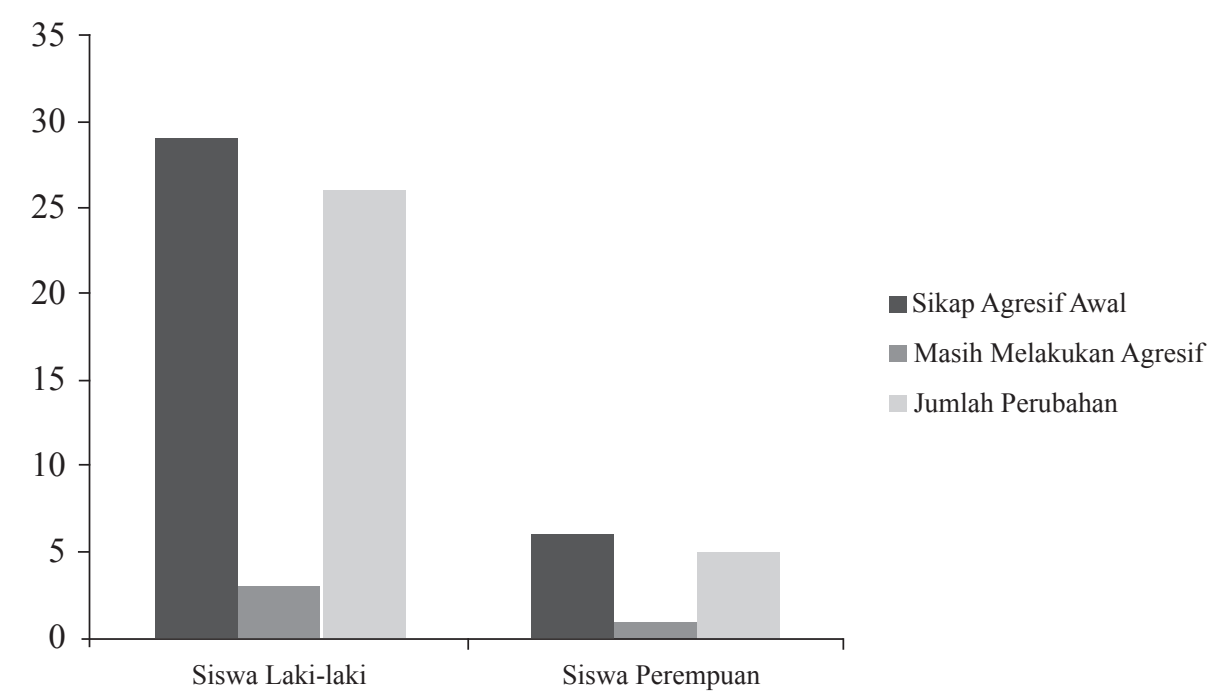

Gambar 6. Diagram Hasil pelaksanaan layanan konseling kelompok siklus II

\section{Refleksi Siklus I}

Berdasar pengamatan perubahan perilaku siswa dalam kegiatan layanan konseling kelompok sudah nampak ada sedikit perubahan yang bisa disaksikan walaupun belum begitu kelihatan karena setelah diberikannya tindakan siklus satu dari hasil pengamatan maupun dari catatan guru bimbingan dan konseling masih ditemui anak yang bertengkar di sekolah meskipun ada pengurangan jumlah peserta didik yang bertengkar di sekolah. Hal ini mungkin lebih memberikan nuansa tersendiri bagi peserta konseling kelompok karena kemungkinan dapat menyentuh perasaan dan pemahaman yang lebih baik pada peserta didik. Mengingat suasana kegiatan bukan seperti suasana belajar mengajar di kelas melainkan suasana yang kekeluargaan, merasa senasib dan sepermasalahan.

Sikap perilaku siswa pada siklus I telah mencapai indikator seperti yang diharapkan meskipun beberapa siswa masih terlihat pasif dalammengikuti layanan hal ini disebabkan karena adanya perbedaan kemampuan individu siswa dalam merespon adanya suatu permasalahan. Oleh karenanya untuk memperbaiki layanan penulis melakukan langkah-langkah sebagai berikut:

a. Memberikan layanan bimbingan secara langsung pada siswa yang kurang aktif dengan memberikan penjelasan ulang.

b. Memberikan kesempatan kepada siswa untuk menanyakan hal-hal yang belum dimengerti.

c. Memberikan kebebasan seluas-luasnya kepada siswa melakukan ekplorasi untuk mengungkapkan segala permasalahan yang ia hadapi. Siswa dipersilahkan mengungkapkan apa yang masih ada dalam benak hatinya sesuai permasalahan yang ia hadapi.

Dari hasil angket terlihat bahwa belum semua siswa berminat terhadap penggunaan metode konseling kelompok dengan bermain peran atau dinamika kelompok, hal ini karena 


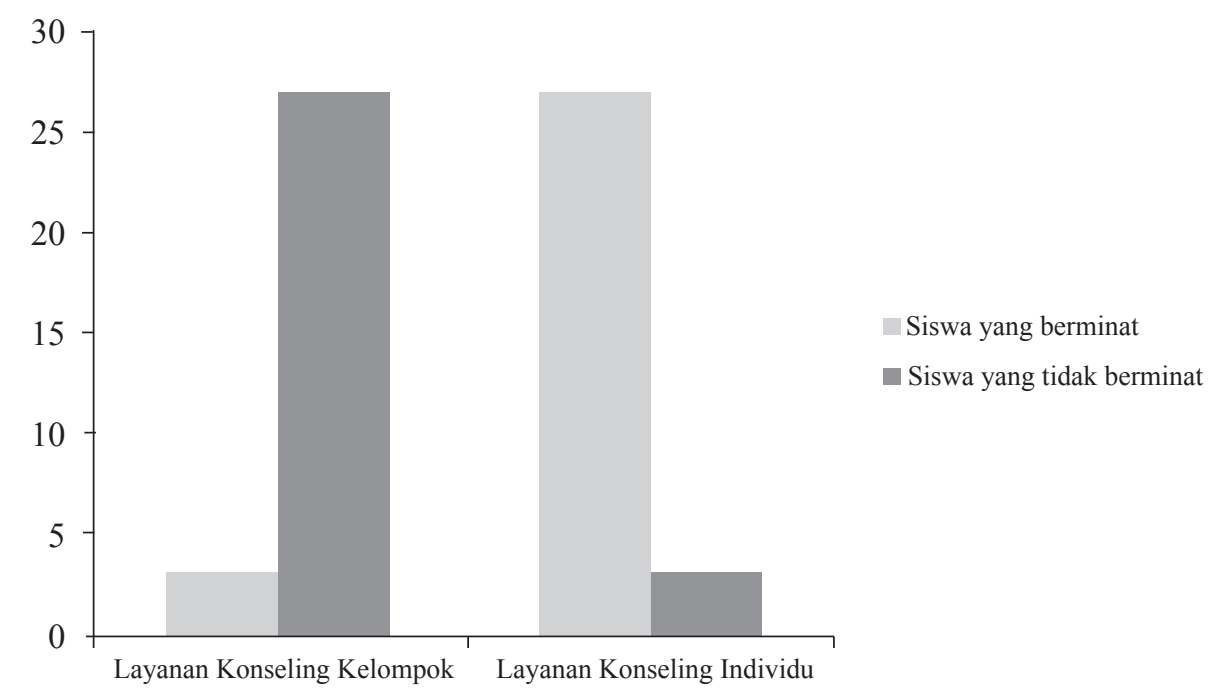

Gambar 7. Diagram Hasil Angket Siswa Siklus II

Tabel 6 Hasil Angket Siswa Siklus II

\begin{tabular}{lcc}
\hline \multicolumn{1}{c}{ Minat siswa } & $\begin{array}{c}\text { Layanan Konseling Kelompok dengan } \\
\text { Metode Dinamika Kelompok }\end{array}$ & Layanan Konseling Individu \\
\hline Berminat & $3(10 \%)$ & $27(30 \%)$ \\
Tidak Berminat & (siswa yang Bermasalah) & (Siswa yang tidak bermasalah) \\
& $27(30 \%)$ & $3(10 \%)$ \\
Jumlah & (Siswa yang tidak bermasalah) & (siswa yang Bermasalah) \\
\hline
\end{tabular}

Sumber: Data Primer Diolah Tahun 2017

Tabel 7. Hasil evaluasi terhadap adanya perubahan pada perilaku agresif siswa Siklus II

\begin{tabular}{|c|c|c|c|c|}
\hline No & $\begin{array}{c}\text { Laki-laki } \\
\text { (Perilaku Agresif } \\
\text { Siklus II) }\end{array}$ & $\begin{array}{l}\text { Laki-laki (Perubahan } \\
\text { Perilaku Agresif Siklus II) }\end{array}$ & $\begin{array}{c}\text { Perempuan } \\
\text { (Perilaku Agresif } \\
\text { Siklus II) }\end{array}$ & $\begin{array}{l}\text { Perempuan (Perubahan } \\
\text { Perilaku Agresif Siklus } \\
\text { II) }\end{array}$ \\
\hline 1 & $3(10 \%)$ & $26(86.6 \%)$ & $6(20 \%)$ & $5(16.6 \%)$ \\
\hline $\begin{array}{l}\text { Jumlah Perubahan } \\
\text { Siswa yang masih } \\
\text { berperilaku agresif }\end{array}$ & Laki-laki & $23(76.6 \%)$ & Perempuan & $1(3.3 \%)$ \\
\hline
\end{tabular}

Sumber: Data Primer Diolah Tahun 2017

ada beberapa siswa belum terbiasa mengikuti kegiatan konseling karena sebelumnya belum pernah ada masalah. Untuk mengatasi hal ini penulis meminta siswa untuk berfikir rileks dan tidak usah bingung ataupun takut dalam menghadapi masalah karena pada dasarnya semua orang pasti punya masalah dan tidak ada masalah yang tidak bisa diatasi tergantung pada niat yang bersangkutan untuk mengatasinya.

Hasil evaluasi terhadap perubahan perilaku agresif siswa pada siklus I belum memenuhi indikator kinerja sebagaimana yang telah ditetapkan. Rendahnya perubahan perilaku agresif siswa dikarenakan kebanyakan siswa belum paham teknik dinamika kelompok dalam konseling kelompok dengan baik. Kebanyakan siswa hanya mengikuti kegiatan layanan apa adanya. Siswa kurang mengerti pikiran apa maksud dan tujuan dari pelaksanaan konseling kelompok yang diadakan oleh guru BK. Guna memperbaiki kegiatan layanan penulis menjelaskan ulang dengan memberikan contoh serta memberikan kesempatan pada siswa untuk menanyakan hal-hal yang belum dimengerti terkait dengan pelaksanaan layanan konseling kelompok yang telah siswa ikuti. 


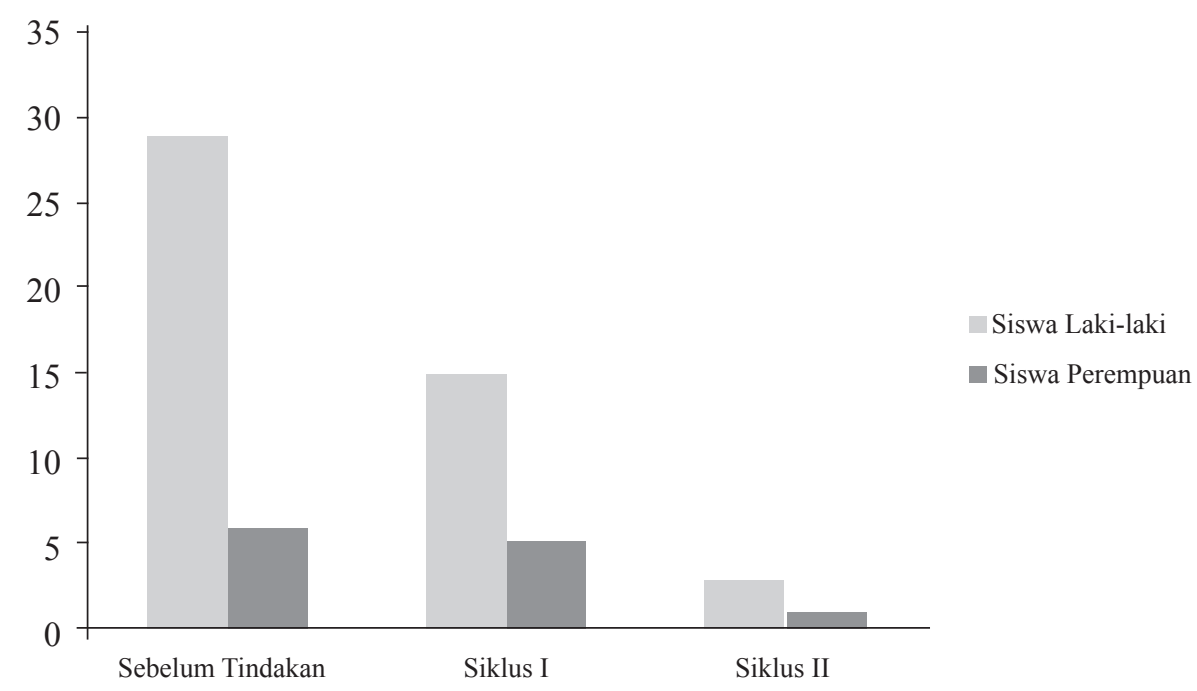

Gambar 8. Diagram perilaku Agresif Sebelum Tindakan, Siklus I dan Siklus II

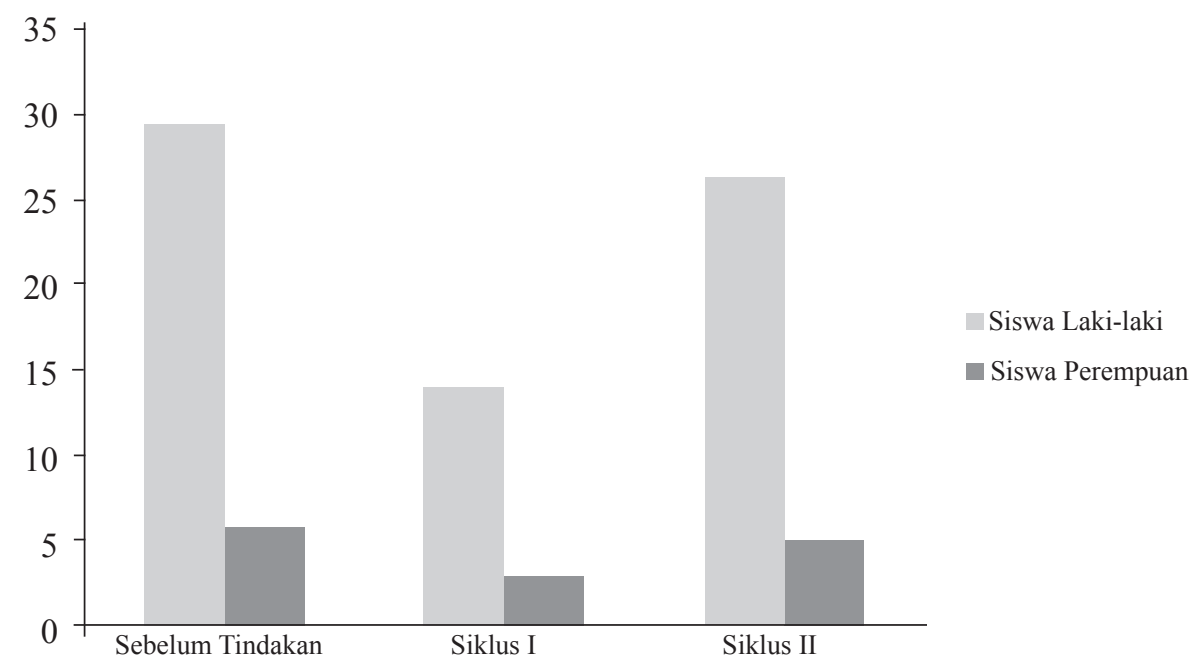

Gambar 9. Perubahan Sikap Perilaku Agresif Siswa Pada Siklus I dan Siklus II

\section{Refleksi Siklus II}

Secara keseluruhan hasil observasi dan evaluasi pada kegiatan layanan konseling pada siklus II telah memenuhi indikator kinerja yang ditetapkan. Oleh karenanya peneliti dalam hal ini tidak akan melanjutkan penelitian ini ke seklus berikutnya karena pada siklus II ini tujuan penelitian telah tercapai. Namun masih ada perhatian kusus dan pemantauan terhadap siswa yang telah berperilaku agresif untuk dua siswa yang masih melakukan tindakan agresif juga sudah mengalami penurunan atau perubahan meski masih dalam pemantauan dan tindak lanjut untuk perhatian kusus. Maka pada penelitian ini penulis dapat menyajikan adanya penurunan perubahan perilaku agresif yang terjadi pada siswa klas $7 \mathrm{f}$ setelah diadakan permainan dinamika kelompok dan konseling kelompok dalam siklus I dan Siklus.

\section{HASIL PEMBAHASAN}

Dilihat dari hasil observasi dan evaluasi dapat diketahui bahwa hasil perubahan sikap dan perilaku agresif pada siswa kelas VII C MTsN Prambanan mengalami penurunan.

Dari tabel 8 dapat disimpulkan bahwa kenakalan perilaku agresif siswa kelas $7 \mathrm{~F}$ mengalami penurunan. Hal ini menandakan bahwa layanan konseling kelompok dengan teknik dinamika kelompok dapat bermanfaat 
sebagai sarana untuk mengurangi sikap perilaku agresif pada siswa. Dari pantaun penulis selama kegiatan layanan konseling kelompok siswa lebih suka memilih bermain peran atau dinamika kelompok untuk memecahkan permasalahan yang ada. Hal ini wajar karena siswa lebih merasa nyaman dan merasa lebih bisa bebas dan mengekpresikan dirinya.

Segi positif penggunaan metode dinamika kelompok dalam konseling kelompok ini adalah lebih dapat menumbuhkan rasa percaya diri pada siswa.

Keberhasil tindakan dalam penelitian tindakan kelas sangat ditentukan oleh hasil evaluasi permasalahan siswa. Dalam penelitian ini hasil evaluasi bmasalah yang telah dilakukan siswa telah mencapai indikator kinerja sebagaimana yang diharapkan. Yaitu suasana kelas lebih terasa nyaman dan kondisif. Selain itu hasil evaluasi layanan konseling pada penelitian ini menunjukkan bahwa penguasaan siswa terhadap kompetensi dasar mengungkapkan pikiran, perasaan, informasi, dan fakta dan permasalahan mengalami penurunan yang segnifikan. Hal ini ditunjukkan dengan jumlah siswa yang mengalami perubahan perilaku agresif semakin menurun dari sebelum penerapan tindakan hingga siklus II telah terjadi perubahan

Setelah penulis memberikan tindakan pada peserta didik kelas 7F dengan layanan konseling kelompok maka diperoleh hasil sebagai berikut:

Dengan diberikannya layanan konseling kelompok peserta didik terlihat gembira dan antusias untuk mengikuti semua kegiatan dengan suka rela dan penuh kesungguhan sehingga pesan atau tujuan yang akan dicapai yaitu penurunan perilaku agresif atau perilaku bertengkar di sekolah dapat dipahami dengan benar dan selanjutnya diwujudkan dalam perilaku sehari hari di sekolah.

Dari data kondisi awal sampai kondisi akhir menunjukkan adanya penurunan atau pengurangan jumlah peserta didik yang berperilaku agresif atau bertengkar di madrasah, dengan 13 jumlah permasalahan dan dengan 29siswa sebagai pelakunya menjadi 3 siswa berarti ada penurunan sebesar $86,6 \%$.

Berdasarkan kenyataan dan pengamatan yang dilakukan layanan konseling kelompok dapat menurunkan jumlah perilaku agresif bertengkar di madrasah karena peserta konseling kelompok benar benar merasa nyaman dan diperhatikan. Mereka tidak merasa di nasihati tetapi mereka merasakan kebersamaan untuk menyelesaikan permasalahan bersama kelompok dalam hal ini adalah penurunan perilaku agresif bertengkar di madrasah pada peserta didik kelas 7F MTsN Prambanan Kabupaten Klaten

\section{KESIMPULAN}

Pada saat kondisi awal, kelas belum diberi layanan konseling kelompok, masih banyak peserta didik yang melakukan perilaku agresif dalam hal ini adalah bertengkar/berkelahi di sekolah/madrasah yaitu mencapai $96.6 \%$. Banyak Guru mengeluh tentang kelas 7F yang emosional dan sering bikin masalah dengan kelas lain. Hal ini dapat dilihat pada buku kasus dan kegiatan konsultasi dan koordinasi guru Pembimbing dengan Kepala Madrasah dan Wali kelas/guru mata pelajaran. Perilaku sikap agresif siswa kelas 7F melalui layanan konseling kelompok pada siklus I 50\% untuk perilaku agresif siswa laki-laki dan $10 \%$ untuk siswa perempuan sehingga dapat menurunkan perilaku agresif bertengkar di sekolah sebesar

Tabel 8 Penurunan sikap prilaku agresif siswa

\begin{tabular}{lccc}
\hline \multicolumn{1}{c}{ Aspek yang diamati } & \multicolumn{2}{c}{ Jumlah siswa } & Penurunan \\
& Siklus I Agresif & Siklus II & $(\%)$ \\
\hline $\begin{array}{l}\text { Sikap Perilaku Agresif } \\
\text { (Mengejek, Berkelahi, }\end{array}$ & 29 siswa (96.6\%) & 3 siswa & 26 siswa \\
Menyakiti, & $(10 \%)$ & $(86,6 \%)$ \\
Pelecehan seksual, & & \\
Usil/Jahil, & & & \\
Saling mengolok-olok dan menghina) & & & \\
\hline
\end{tabular}

Sumber: Data Primer Diolah Tahun 2017 
$96.6 \%$ menjadi $36.6 \%$ dengan jumlah penurunan dari 29 peserta didik berperilaku agresif dalam dua minggu berkurang menjadi 18 peserta didik. Dengan penurunan jumlah peserta didik sebanyak 11 peserta didik kemudian pada siklus II dari $96.6 \%$ mengalami penurunan lagi menjadi $10 \%$ yang berarti ada perubahan sebesar $86.6 \%$ ini merupakan penurunan yang cukup signifikan. Hal ini menunjukkan bahwa melalui pemberian layanan konseling kelompok dapat menurunkan perilaku agresif bertengkar di sekolah pada peserta didik kelas 7F MTsN Prambanan Kabupaten Klaten.

\section{DAFTAR PUSTAKA}

Anantasari. 2006. Psikologi Sosial. Jakarta: Gramedia.
Iskandar. 2009. Penelitian Tindakan Kelas. Jakarta; Gaung Persada.

Kurt Singer. 1991. Psikologi Sosial. Surabaya: Airlangga.

Latipun. 2000. Bimbingan dan Konseling. Jakarta: Erlangga.

Prayitno. 2004. Pelayanan Konseling di Sekolah Padang: Universitas Negeri Padang.

Shertzer and Stone. 1980. Fundamentals of Counseling. New York: MC Graw Hill.

Suharsimi Arikunto,2006. Penelitian Tindakan Kelas.Bumi Aksara:Jakarta

Winkel. 2002. Bimbingan dan Konseling di Sekolah. Yogyakarta: Universitas Sanata Darma.

Zainal Aqib. 2009. Penelitian Tindakan Kelas. Bandung: Yrama Widya. 